\title{
Обумовленість ЄС як рушійна сила європейської інтеграції країн Західних Балкан
}

\section{Рудік О. О., Дніпровський національний університет ім. Олеся Гончара}

На основі результатів аналізу розробленої Європейською Комісією стратегії «Надійна перспектива розширення та посилення співпраці ЄС з країнами Західних Балкан» досліджено роль обумовленості ЄС в процесі європейської інтеграції країн регіону. В стратегії чітко зазначено, що сьогодні у країн регіону відкрилось історичне «вікно можливостей», щоб твердо і однозначно пов'язати своє майбутнє з ЄС. ЄС вимагає від західнобалканських країн рішучих дій та термінового подвоєння зусиль щодо проведення життєво важливих реформ - особливо в сфері верховенства права, незалежності судової системи, основоположних прав людини та громадянина, належного врядування - для завершення своїх політичних, економічних та соціальних перетворень. Для забезпечення належної підтримки трансформаційних процесів в регіоні ЄС зобов'язується вдосконалювати політику розширення та інструменти передвступної допомоги. Стратегія визначає План дій із шістьма флагманськими ініціативами, спрямованими на конкретні сфери взаємного інтересу: верховенство права, безпека та міграція, соціально-економічний розвиток, комунікації, цифрові технології, примирення та добросусідські відносини. Встановлено, що обумовленість ЄС залишається рушійною силою європейської інтеграції країн Західних Балкан. В політиці розширення Європейська Комісія продовжує керуватись так званою моделлю зовнішнього стимулювання, поєднуючи у відносинах з країнами регіону певні винагороди і покарання.

Ключові слова: міжнародні відносини; європейська інтеграція; посткомуністичні країни; процес розширення СС; обумовленість; критерії членства

\section{EU conditionality as a driving forceof the Western Balkans European integration}

\section{Rudik O. O., Oles Honchar Dnipro National University}

The Western Balkans European integration is in the EU's very own political, security and economic interest. The European Commission considers the countries of the region membership perspective as a geostrategic investment in a stable, strong and united Europe based on common values. It is also a powerful tool to promote democracy, the rule of law and the respect for fundamental rights. A credible accession perspective is the key driver of transformation in the region and thus enhances integration processes, security, prosperity and social well-being. It remains essential for fostering reconciliation and stability in the conflict-generating region.

This article explores the role of the EU conditionality in the process of the Western Balkans countries European integration, based on the analysis of the European Commission's strategy «A credible enlargement perspective for and enhanced EU engagement with the Western Balkans». The strategy clearly states, that the countries of the region now have a historic window of opportunity to firmly and unequivocally bind their future to the EU. The EU requires the Western Balkans countries to act with determination and urgently redouble their efforts, address vital reforms - notably in the area of rule of law, independence of the judiciary and fundamental rights, good governance - and complete their political, economic and social transformation. For its part, the EU will be upgrading its enlargement policy and preaccession instruments to better support the transformation process in the region. The Strategy sets out an Action Plan with six concrete flagship initiatives, targeting specific areas of common interest: rule of law, security and migration, socioeconomic development, communications, digital agenda, reconciliation and good neighborly relations.

It should be mentioned, that the Commission is not changing its enlargement policy regarding the Western Balkans: the process is and remains merit-based and each country will be assessed on its own achievements. As in the previous waves of EU's expansion towards the post-communist area in $2004-2013$, the Union will assess the readiness of each candidate country based on its own achievements. The EU emphasizes, that there will be no further enlargement during the mandate of this Commission and in the present term of the European Parliament, but thereafter the European Union will be greater than 27 member states. Accession negotiations are already well underway with Montenegro and Serbia. The Commission is convinced that with strong political will, the delivery of real and sustained reforms, and definitive solutions to disputes with neighbors, the two countries could potentially be ready for membership in a 2025 perspective.

It has been established, that the EU conditionality remains the driving force of the Western Balkans European integration. In its enlargement policy the European Commission continues to be guided by the so-called external incentives model, combining rewards and punishments in relations with the countries of the region. Obviously, for the Western Balkans countries the most severe punishment for the lack of progress in the reforms will be the loss of the membership perspective.

Keywords: International relations; European integration; post-communist countries; EU enlargement; conditionality; membership criteria 


\title{
Обусловленность ЕС как движущая сила европейской интеграции стран Западных Балкан
}

\author{
Рудик А. А., Днепровский национальный университет им. Олеся Гончара
}

На основе результатов анализа разработанной Европейской Комиссией стратегии «Надежная перспектива расширения и усиления сотрудничества ЕС со странами Западных Балкан» исследована роль обусловленности ЕС в процессе европейской интеграции стран региона. В стратегии четко отмечено, что сегодня у стран региона открылось историческое «окно возможностей», чтобы твердо и однозначно связать свое будущее с ЕС. ЕС требует от западнобалканских стран решительных действий и срочного удвоения усилий по проведению жизненно важных реформ - особенно в сфере верховенства права, независимости судебной системы, основных прав человека и гражданина, надлежащего управления - для завершения своих политических, экономических и социальных преобразований. Для обеспечения надлежащей поддержки трансформационных процессов в регионе ЕС обязуется совершенствовать политику расширения и инструменты подготовки ко вступлению. Стратегия определяет План действий с шестью флагманскими инициативами, направленными на конкретные сферы взаимного интереса: верховенство права, безопасность и миграция, социально-экономическое развитие, коммуникации, цифровые технологии, примирения и добрососедские отношения. Установлено, что обусловленность ЕС остается движущей силой европейской интеграции стран Западных Балкан. В политике расширения Европейская Комиссия продолжает руководствоваться так называемой моделью внешнего стимулирования, сочетая в отношениях со странами региона определенные вознаграждения и наказания.

Ключевые слова: международные отношения; европейская интеграция; посткоммунистические страны; процесс расширения ЕС; обусловленность; критерии членства

\section{Постановка проблеми.}

7 ахідні Балкани є частиною Європи, гео$\mathcal{2}$ графічно оточеної державами-членами

$\mathcal{C C . ~ Н а р о д и ~} €$ С та регіону мають не лише спільну спадщину та історію, а також і майбутнє, яке визначається спільними можливостями та викликами. СС вже досить давно активно працює в цьому регіоні. В 2003 р. на саміті ЄС в Салоніках європейські лідери підтримали майбутнє регіону як невід'ємної частини ЄС [3]. Відтоді чотири країни регіону - Албанія, Македонія, Сербія, Чорногорія - стали кандидатами на вступ в $С \mathrm{C}$, а ще дві (Боснія і Герцеговина, Косово) - потенційними кандидатами.

Надання країнам регіону чіткої європейської перспективи допомогло їм провести базові політичні та економічні реформи та поліпшити демократичні процеси. Візова лібералізація з $\mathrm{EC}$ та значно посилена регіональна співпраця істотно посприяли формуванню в цих країнах більш відкритих суспільств та сучасних ринкових економік. Так, згідно з останнім за часом рейтингом Freedom House, одна $з$ країн регіону має статус вільної демократії (Сербія), а решта - частково вільних електоральних демократій [5] Щодо економіки, то в 2016 р. загальний вартісний обсяг торгівлі регіону з СС склав понад 43 млрд. євро, що на 80 $\%$ більше, ніж в 2008 р. та зі значним додатковим потенціалом зростання. Компанії ЄС також $є$ найбільшими інвесторами в регіоні Західних Балкан, забезпечивши понад 10 млрд. євро прямих іноземних інвестицій лише за останні п’ять років [1, p. 1] Зв'язок та взаємозалежність регіону з СС стали ще більш очевидними під час європейської міграцій- ної кризи 2014-2016 рр. Країни регіону все більше виступають як партнери СС на світовій арені.

Європейська інтеграція країн Західних Балкан $€$ безумовним політичним, безпековим та економічним інтересом ЄС. Свропейська Комісія розглядає перспективу членства цих країн в $С С$ як геостратегічну інвестицію в стабільну, міцну та об'єднану Європу, засновану на спільних цінностях, а також як потужний інструмент для просування демократії, верховенства права та поваги до основоположних прав і свобод людини [1]. Надійна перспектива вступу $є$ ключовим чинником трансформації в регіоні, що посилює інтеграційні процеси, сприяє досягненню спільної безпеки, процвітання та соціального благополуччя. Свропейська інтеграція залишається важливим чинником примирення та стабільності в цьому вкрай конфліктогенному регіоні.

\section{Аналіз досліджень і публікацій.}

Європейська інтеграція Західних Балкан постійно знаходиться в центрі уваги учених, оскільки країни регіону, які досить давно мають чітку перспективу вступу, перебувають нині у складних трансформаційних процесах, обумовлених вимогами СС. Серед публікацій у цій сфері, що заслуговують на увагу, слід відзначити праці М. Домбровського, Я. М'яченкової, Т. Бержель, С. Грімм, Р. Беллоні, М. Брунаццо, А. Юнкос, С. Село Шабіч, А. Ельбасані, Ф. Шиммельфеніга, У. Седелмейєра, К. Сай, Т. Павасович Трошт та інших науковців. Наукові праці цих учених присвячені аналізу політичних, соціально-економічних, безпекових, екологічних та інших аспектів європейської інтеграції країн Західних Балкан, перспектив їх член- 
ства, дослідженню політики ЄС в регіоні та ролі європейської обумовленості в процесі стабілізації, економічного відродження та демократизації Західних Балкан.

Метою статті є з'ясування ролі і значення обумовленості ЄС в процесі європейської інтеграції країн Західних Балкан на сучасному етапі на основі аналізу останньої за часом стратегії Союзу щодо посилення співпраці з країнами регіону у контексті перспективи їх майбутнього вступу.

\section{Виклад основного матеріалу.}

Політика розширення ЄС має бути невід'ємною частиною більшої стратегії зміцнення Союзу до 2025 р., викладеної Головою Європейської Комісії Ж.-К. Юнкером в його посланні «Про становище ЄС» у вересні 2017 р. [7]. Це інвестиції в безпеку, економічний розвиток та вплив $\mathrm{CC}$, а також в його здатність захищати своїх громадян. На виконання «Дорожньої карти для більш об'єднаного, сильного та демократичного Союзу» [9], Комісія протягом 2018 р. на основі чинних установчих договорів планує висунути низку ініціатив, спрямованих на вдосконалення демократичної, інституційної та політичної основи Союзу до 2025 р. Зокрема, ці ініціативи включатимуть пропозиції щодо підвищення ефективності прийняття рішень в СС шляхом удосконалення процедури голосування кваліфікованою більшістю у таких сфеpax, як зовнішня політика або внутрішній ринок.

Частиною вищезгаданої дорожньої карти стала оприлюднена в повідомленні Комісії від 6 лютого 2018 р. стратегія «Надійна перспектива розширення та посилення співпраці СС 3 країнами Західних Балкан» (далі - Стратегія) [1]. В Стратегії чітко окреслені актуальні проблеми, з якими стикаються країни Західних Балкан під час процесу європейської інтеграції. У зв'язку з цим СС пропонує країнам регіону нові потужні стимули для проведення реформ, а також надає рекомендації щодо кроків, необхідних для якнайшвидшого просування шляху вступу в СС.

В СС наголошують, що розширення Союзу не відбудеться до завершення в 2019 р. мандату нинішньої Європейської Комісії та каденції Європейського Парламенту 2014 р. скликання. Однак до 2025 р. у складі ЄС може бути більше, ніж 27 держав-членів. Переговори про вступ досить успішно ведуться із Чорногорією (з початку переговорів про вступ в червні 2012 р. відкрито переговори стосовно 30 -ти розділів асquis 3 35-ти [13]) та Сербією (з початку переговорів про вступ в січні 2014 р. відкрито переговори стосовно 12-ти розділів асquis з 35-ти [6]). В СС переконані, що за наявності сильної політичної волі, проведення реальних і стабільних реформ, а також за умови остаточного вирішення суперечок з сусідами, ці країни потенційно можуть бути готові до набуття членства в 2025 р. Комісія підкреслює, що досягнення цієї надзвичайно амбіційної мети цілком залежить від об'єктивних заслуг і результатів кожної країни [1, p. 3].

У Стратегії чітко зазначено, що двері СС відкриті для подальшого вступу нових держав-членів. Більше того, на думку Європейської Комісії, саме тепер перед західнобалканськими країнами відкрилось історичне «вікно можливостей», щоб твердо і однозначно пов'язати своє майбутнє 3 ЄC [1, p. 3]. Однак, їм доведеться рішуче діяти, оскільки вступ в ЄС є і залишатиметься заснованим на заслугах процесом, повністю залежним від об'єктивного прогресу, досягнутим кожною країною-кандидатом. Під час цього процесу країни можуть наздогнати або переганяти один одного залежно від досягнутого ними прогресу у виконанні критеріїв та вимог СС [8].

Слід зазначити, що Комісія жодним чином не змінює свою політику розширення стосовно країн регіону Західних Балкан. Як і під час попередніх хвиль розширення на посткомуністичний простір в 2004-2013 pp., ЄС оцінюватиме готовність до вступу кожної країни-кандидата на основі ії власних досягнень. Тобто йдеться про вже неодноразово застосовану на практиці модель зовнішнього стимулювання, за якої національні уряди волітимуть приймати правила і норми Союзу, якщо вигоди від винагород $\mathrm{CC}$ перевищуватимуть внутрішні витрати на прийняття цих правил і норм. Ф. Шиммельфеніг та У. Седелмеєр вважають, що цей баланс вигід-витрат залежатиме від чотирьох груп факторів: 1) визначеність умов; 2) розмір винагород та швидкість їх надання; 3) вірогідність покарань і обіцянок (обумовленості); 4) розмір витрат на прийняття (рецепцію) правил і норм [11, p. 12-17]. В процесі переговорів про вступ ЄС також широко застосовує стратегію «посилення винагородою», яка полягає в припиненні або призупинені преференцій з боку $\mathrm{CC}$, які він надає країнам-бенефіціарам у формі встановлення відповідних інституційних зв'язків і надання фінансової допомоги, у разі якщо політика і дії цільового національного уряду не відповідають демократичним стандартам [10, p. 497)].

У Стратегії Європейська Комісія оголосила про шість «флагманських ініціатив» - конкретних дій, які $Є С$ візьме на себе протягом найближчих років, щоб підтримати зусилля 3 трансформації Західних Балкан у сферах, що становлять взаємний інтерес [1, p. 10-15; 4]:

1. Посилена підтримка верховенства права. Ініціатива передбачає поширення на країни регіону таких існуючих в ЄС інструментів ведення переговорів, як детальні плани дій. Буде посилена оцінка імплементації реформ, зокрема за допомогою нових консультативних місій в усіх країнах 
регіону. Ширше використовуватимуться важелі, надані СС у межах переговорів про вступ з Сербією та Чорногорією.

2. Посилення взаємодії з питань безпеки та міграції. Ініціатива спрямована на поглиблене співробітництво в боротьбі з організованою злочинністю, протидії тероризму та насильницькому екстремізму, а також з питань безпеки кордонів та управління міграцією. В регіоні будуть розміщені співробітники по зв'язках Європолу та дістануть подальшу підтримку спільні слідчі групи. Будуть укладені угоди про статус з Свропейським агентством охорони сухопутних та морських кордонів (Frontex).

3. Підтримка соціально-економічного розвитку. Ініціатива включатиме розширення фінансового інструменту «Рамковий інвестиційний механізм Західних Балкан», суттєву активізацію положень щодо надання гарантій для залучення приватних інвестицій, підтримки стартапів та малих і середніх підприємств, сприяння торгівлі. У новому посиленому соціальному вимірі більше уваги приділятиметься питанням зайнятості та соціальній політиці, буде збільшено фінансову допомогу для підтримки соціальної сфери, зокрема освіти та охорони здоров'я, а також подвоїться фінансування за програмою Erasmus + .

4. Розширення комунікаційних можливостей. Ініціатива передбачає збільшення транспортної та енергетичної взаємодії в регіоні та ЄС, включаючи нову інвестиційну підтримку. В регіоні ефективніше використовуватимуться кошти фонду «Підключення до Європи». Для зміцнення Енергетичного союзу $\mathrm{CC}$ всі його виміри мають бути поширені на Західні Балкани.

5. Ініціювання Порядку денного в сфері цифрових технологій для Західних Балкан. Включатиме дорожню карту заходів щодо зниження витрат на роумінг, підтримку розгортання в регіоні широкосмугового зв'язку, розвитку електронного урядування, електронних закупівель, електронної охорони здоров'я та навичок роботи 3 цифровими технологіями.

6. Підтримка примирення та добросусідських відносин. Ця ініціатива включатиме підтримку правосуддя перехідного періоду, посилення регіональної співпраці для вирішення проблеми зниклих безвісти, посилення співпраці в галузі освіти, культури, молоді та спорту, а також розширення сфери діяльності Регіонального бюро молодіжного співробітництва.

Додатком до Стратегії є «План дій на підтримку трансформації Західних Балкан», що містить основні заходи, які слід виконати в межах кожної 3 флагманських ініціатив у період 2018-2020 pp. [2] Фактично, ці заходи $є$ кроками, які країни регіони мають зробити, щоб завершити процес вступу на перспективу з 2025 р. Однак, на думку Комісії, планом дій у першу чергу можуть скористатись Сербія і Чорногорія, які на даний момент є єдиними країнами-кандидатами, з якими $Є С$ розпочав переговори про вступ. Так, Македонії слід досягнути конкретних результатів реформ, особливо у сферах верховенства права, боротьбі з корупцією та організованою злочинністю. Сербії слід досягнути національного консенсусу щодо реформ, необхідних для утвердження верховенства права $і$ зростання економіки, а також для сприяння процесу примирення. Останнє є серйозним викликом для країни, оскільки $Є С$ наполягає на укладенні та імплементації ще до моменту вступу всебічної юридично зобов'язуючої угоди про нормалізацію відносин з Косово [8].

У Стратегії підкреслюється необхідність готовності ЄС до чергового етапу розширення, після того як країни-кандидати виконають всі критерії вступу. У зв'язку з цим Комісія виділила три важливих питання [1, p. 15-17]:

1. Інституційні. Перед тим як стати більшим Союз має бути сильнішим і міцнішим. Виходячи 3 цього постулату, Комісія в третьому кварталі 2018 p. планує виступити з ініціативою щодо підвищення ефективності процесу прийняття рішень в $\mathrm{EC}$, зокрема процедури голосування кваліфікованою більшістю в Раді СС [12; 7]. Більш ефективна система також необхідна для подолання системних загроз або порушень верховенства права в будь-якій державі-члені, оскільки членство в ЄС означає прийняття та зміцнення його основоположних цінностей. Європейська Комісія вважає, що правовою основою такого механізму могли б стати договори про вступ, які ЄС укладає з країнами-вступниками після успішного завершення переговорів про вступ. Необхідно також запровадити спеціальні домовленості та беззаперечні зобов'язання для забезпечення того, щоб майбутні держави-члени не могли блокувати вступ в СС інших країн-кандидатів регіону. Нарешті, задовго до завершення переговорів про вступ Комісія планує надати оцінку впливу приєднання нових держав-членів на такі ключові сфери політики СС, як сільське господарство, згуртування та бюджет. Це дозволить державам-членам визначати спільні позиції $€$ с стосовно відповідних розділів acquis та вжити необхідних пом'якшувальних заходів.

2. Надання фінансових коштів для успішного вступу. ЄС підтримує процес підготовки до вступу країн Західних Балкан та сприяє їх регіональному і транскордонному співробітництву за допомогою Інструменту передвступної допомоги, у межах якого в 2007-2017 рр. в цей регіон було інвестовано більше 8,9 млрд. євро, а в 2018 р. очікується виділення 1,07 млрд. євро. Комісія обіцяє, що фінансування підготовки до вступу буде більше 
відповідати потребам країн регіону, а також поступово збільшуватиметься 3 огляду на потребу фінансування Стратегії. Комісія спеціально наголошує на посиленні обумовленості двосторонньої допомоги ЄС. Збільшення обсягів фінансування як у межах чинного, так і наступного Багаторічного фінансового плану СС має бути пов'язане 3 прогресом у здійсненні країнами регіону фундаментальних реформ та зміцненні добросусідських відносин між ними.

3. Комунікація. Для того, щоб процес вступу був успішним, його можливості та виклики мають бути чіткіше доведені до відома як країн регіону, так і ЄС загалом. Комісія підкреслює, що надання адекватної інформації громадянам і бізнесу, a також формування національного консенсусу щодо стратегічної мети вступу в $Є \mathrm{C}, \epsilon$ сферою відповідальності урядів країн регіону. У свою чергу, СС і держави-члени також мають належним чином інформувати своїх громадян щодо можливостей та викликів процесу розширення Союзу на Західні Балкани. Комісія підтримуватиме ці зусилля шляхом активізації стратегічної комунікації в країнах регіону і в Союзі та забезпечення достатньої інформації щодо політики розширення.

\section{Висновки.}

Таким чином, обумовленість СС залишається рушійною силою європейської інтеграції країн Західних Балкан. У політиці розширення Свропейська Комісія продовжує керуватись так званою моделлю зовнішнього стимулювання, поєднуючи у відносинах з країнами регіону певні винагороди і покарання. У Стратегії чітко зазначено, що перспектива розширення Союзу на Західні Балкани передусім залежить від самих країн регіону. Свропейська Комісія відверто говорить у Стратегії, що у країн регіону відкрилось історичне «вікно можливостей», щоб твердо і однозначно пов'язати своє майбутнє з ЄС. Очевидно, що найсуворішим покаранням за відсутність поступу у реформах буде втрата перспективи вступу. Запропонувавши у якості винагороди чітку і недвозначну перспективу вступу та збільшення обсягу необхідної фінансової і технічної передвступної допомоги, ЄС вимагає від західнобалканських країн діяти рішуче та терміново подвоїти свої зусилля щодо проведення життєво важливих реформ - особливо в сфері верховенства права, незалежності судової системи, основоположних прав людини та громадянина, належного врядування - i, нарешті, завершити свої політичні, економічні та соціальні перетворення. Важливими пріоритетами є також підвищення конкурентоспроможності економік та підтримання в регіоні миру і добросусідських відносин. Для забезпечення належної підтримки трансформаційних процесів у регіоні ЄС зобов'язується вдосконалювати політику розширення та інструменти передвступної допомоги. Розроблена ЄС Стратегія визначає План дій із шістьма флагманськими ініціативами, спрямованими на конкретні сфери взаємного інтересу: верховенство права, безпека та міграція, соціально-економічний розвиток, комунікації, цифрові технології, примирення та добросусідські відносини.

\section{REFERENCES}

1. A credible enlargement perspective for and enhanced EU engagement with the Western Balkans: Communication from the Commission to the European Parliament, the Council, the European Economic and Social Committee and the Committee of the Regions. Strasbourg, 6.2.2018 COM(2018) 65 final. Retrieved from: https://ec.europa.eu/commission/ sites/beta-political/files/communication-credible-enlargement-perspective-western-balkans_en.pdf

2. Annex to the Communication from the Commission to the European Parliament, the Council, the European Economic and Social Committee and the Committee of the Regions "A credible enlargement perspective for and enhanced EU engagement with the Western Balkans». Strasbourg, 6.2.2018 COM (2018) 65 final. Retrieved from: https://ec.europa.eu/ commission/sites/beta-political/files/annex-communication-credible-enlargement-perspective-western-balkans_en.pdf 3. EU - Western Balkans Summit. Thessaloniki, 21 June 2003. Retrieved from: http://europa.eu/rapid/press-release PRES-03-163 en.htm

4. European Commission Factsheet - Six new flagship initiatives to support the transformation of the Western Balkans. Retrieved from: https://ec.europa.eu/commission/sites/beta-political/files/six-flagship-initiatives-support-transformationwestern-balkans_en.pdf

5. Freedom in the World 2018. Democracy in Crisis. Retrieved from: https://freedomhouse.org/report/freedom-world/ freedom-world-2018

6. Milestones in EU - Serbia relations. The Delegation of the European Union to the Republic of Serbia. Retrieved from: http://europa.rs/serbia-and-the-eu/milestones/?lang=en

7. President Jean-Claude Juncker's State of the Union Address 2017. European Commission - Speech. Brussels, 13 September 2017. Retrieved from: http://europa.eu/rapid/press-release_SPEECH-17-3165_en.htm

8. Q\&A: A credible enlargement perspective for and enhanced EU engagement with the Western Balkans. European Commission - Fact Sheet. Brussels, 6 February 2018. Retrieved from: http://europa.eu/rapid/press-release_MEMO-18562 en.htm

9. Roadmap for a More United, Stronger and More Democratic Union. Informal Dinner of Heads of State or Government ahead of the Tallinn Summit. Retrieved from: https:/ec.europa.eu/commission/sites/beta-political/files/roadmap- 
factsheet-tallinn_en.pdf

10. Schimmelfennig, F., Engert, S., \& Knobel, H. (2003). Costs, Commitment and Compliance: The Impact of EU Democratic Conditionality in Latvia, Slovakia and Turkey. In Journal of Common Market Studies, 41, 495-518.

11. Schimmelfennig, F., \& Sedelmeier, U. (2005). Introduction: Conceptualizing the Europeanization of Central and Eastern Europe. In The Europeanization of Central and Eastern Europe. Ithaca; London: Cornell University Press.

12. Strategy for the Western Balkans: EU sets out new flagship initiatives and support for the reform-driven region. European Commission. Press release. Strasbourg, 6 February 2018. Retrieved from: http://europa.eu/rapid/press-release_ IP-18-561 en.htm

13. The European Union in Montenegro. The Delegation of the European Union to Montenegro. Retrieved from: http:// www.delmne.ec.europa.eu/code/navigate.php? $\mathrm{Id}=56$

\section{Рудік Олександра Олександрівна}

Аспірантка

Дніпровський національний університет ім. Олеся Гончара

49000, м. Дніпро, пр. Гагаріна, 72

\section{Rudik Oleksandra}

Post-graduate-student

Oles Honchar Dnipro National University

72, Gagarin ave., Dnipro, 49000, Ukraine

ORCID: 0000-0002-0866-3752_Ｅmail: rudichka.08@gmail.com

Цитування: Рудік О. О. Обумовленість СС як рушійна сила європейської інтеграції країн Західних Балкан / О. О. Рудік // Науково-теоретичний альманах «Грані». - 2018. - Т. 21. - № 3. - С. 102-107.

Citation: Rudik, O.O. (2018). Obumovlenist YeS yak rushiina syla yevropeiskoi intehratsii krain Zakhidnykh Balkan [EU conditionality as a driving force of the Western Balkans European integration]. Scientific and theoretical almanac «Grani», 21(3), 102-107. 